\title{
MENINGKATKAN KEAKTIFAN SISWA PADA KOMPETENSI DASAR MEMPERTAHANKAN KEMERDEKAAN INDONESIA MELALUI MODEL PEMBELAJARAN CARD SORT PADA SISWA KELAS IX SMP NEGERI 3 PONOROGO
}

\author{
Sundari \\ Guru IPS SMP Negeri 3 Kecamatan Ponorogo \\ Email: honocoroko.jos@gmail.com
}

\begin{abstract}
Abstrak
Pembelajaran aktif perlu ditekankan sebagai aspek penting dan sangat berarti dalam menciptakan pembelajaran IPS, agar siswa tidak monoton dan dinamis. Selama ini siswa klas IX E SMP Negeri 3 Kecamatan Ponorogo seringkali mengalami kesulitan dalam menyelesaikan soal IPSkarena itu perlu adanya penggunaan model pembelajaran yang dilakukan oleh guru. Model pembelajaran aktif Card Sortadalah kolaboratif yang mengejar konsep, karakteristik, klasifikasi, fakta, tentang obyek atau mereview informasi. Penelitian Tindakan Kelas ini ini bertujuan untuk mengetahui apakah pembelajaran IPS melalui pembelajaran aktif tipe Card Sort dapat meningkatkan keaktifan siswa dalam menyelesaikan soal IPS. Teknik analisis data dilakukan secara deskriptif kualitatif.Pengumpulan data dilakukan dengan observasi, wawancara, dokumentasi, angket dan catatan lapangan.Hasil dari penelitian ini menunjukkanbahwa penggunaan pendekatan model pembelajaran card sort dapat meningkatkan keaktifan siswa pada kompetensi dasar Mempertahankan Kemerdekaan Indonesia di atas $75 \%$.
\end{abstract}

Kata Kunci: Kompetensi Dasar, Keaktifan Siswa, Card Sort, IPS

\section{Developing Students' Activeness on Based Competences to Defend Indonesian Independence through Card Sort Learning Model for the Ninth Students of SMP Negeri 3 Ponorogo}

\begin{abstract}
Active learning needs to be emphasized as an important aspect and it is very important to create dynamic and not monotonous social science teaching learning. The ninth students of class E, SMP Negeri 3 Ponorogo district often face difficulties during finishng social science test items. It is, therefore, needed the use of a certain learning model that is done by a teacher. Active learning model Card Sort is a collaborative model searching the concept, characteristics, clascification, facts of objects or reviewing an information. The study used classroom action research design aiming to know whether teaching social science through learning model Card Sort can improve students'activeness in finishing social science test items. Data were analyzed by using descriptive qualitative. The data were collected through observation, interview, documentation, questionnaires, and field notes. The results show that menunjukkan bahwa the implementation of learning model card sort can improve students' activeness on based competences to defend Indonesian independence in the level of $75 \%$ above.
\end{abstract}

Keywords: Based competences, students' activeness, card sort, social science

\section{Pendahuluan}

Proses belajar mengajar yang dikembangkan di kelas umumnya ditentukan oleh peran guru dan siswa sebagai individuindividu yang terlibat langsung di dalam proses tersebut. Dalam proses ini siswa SMP Negeri 3 Kecamatan Ponorogo seringkali mengalami kesulitan dalam menyelesaikan soal-soal IPS yang panjang dan butuh analisa maupun hafalankhususnya pada Kompetensi 
Dasar Mempertahankan Kemerdekaan Indonesia. Untuk itu selama proses kegiatan belajar berlangsung, bantuan guru sangat diperlukan. Oleh karena itu kemampuan serta kesiapan guru dalam mengajar memegang peranan penting bagi keberhasilan proses pembelajaran pada siswa.Keberhasilan proses pembelajar pada siswa jika dapat mencapai Kriteria Ketuntasan Minimal (KKM).

KKM mata pelajaran IPS di SMP Negeri 3 Ponorogo adalah 75 dengan ketuntasan klasikal $75 \%$. Hal ini berarti bahwa seorang siswa dikatakan telah berhasil atau tuntas belajarnya jika telah mencapai nilai 75 , dan kelas dinyatakan telah berhasil atau tuntas belajarnya apabila sekurangkurangnya $75 \%$ siswa telah tuntas belajarnya. Namun kenyataan yang ditemukan pada pembelajaran IPS di kelas IX.H SMP Negeri 3 Kecamatan Ponorogo menunjukkan dari 27 siswa yang ikut ulangan harian hanya 15 siswa yang mencapai di atas KKM yang ditentukan,dan rata-rata nilai 65 .

Mencermati berbagai kecenderungan situasi yang muncul pada kelas IX.H SMP Negeri 3 Kecamatan Ponorogo tersebut maka sangat perlu adanya penggunaan strategi pembelajaran yang dilakukan oleh guru. Dari beberapa strategi pembelajaran, terdapat strategi pembelajaran yang menarik dan dapat memicu siswa pada kelas IX.H SMP Negeri 3 Kecamatan Ponorogo untuk ikut serta secara aktif dalam kegiatan belajar mengajar yaitu model pembelajaran aktif tipe Card Sort. Strategi ini perlu ditekankan sebagai aspek penting dan sangat berarti dalam menciptakan pembelajaran IPS. Pertama harapan untuk membuat siswa lebih aktif dan tidak monoton. Kedua, membuat situasi proses pembelajaran lebih familiar sehingga dinamis dalam kelas yang tidak membosankan dan menjenuhkan. Ketiga, Card Sort memberikan kesempatan kepada siswa untuk menemukan (inquiry) sendiri sehingga apa yang didapatkan tidak mudah dilupakan.keempat bertujuan untuk mengungkapkan daya ingat( recoll) terhadap materi pelajaran yang telah di pelajari siswa. Karena siswa yang aktif dalam proses belajar mengajar dapat dengan mudah memahami apa yang di pelajari dan memiliki pengaruh dalam menyelesaikan soal-soal IPS dengan baik.

Berdasarkan analisis situasi di kelas IX. H SMP Negeri 3 Kecamatan Ponorogo. maka rumusan masalah dalam penelitian ini adalah “Apakah pembelajaran IPS melalui pembelajaran aktif tipe Card Sort dapat meningkatkan keaktifan siswa dalam menyelesaikan soal IPS pada Kompetensi Dasar Mempertahankan Kemerdekaan Indonesia mencapai 75\%".Sejalan dengan permasalahan di atas maka secara garis besar penelitian ini bertujuan untuk mengetahui apakah pembelajaran IPS melalui pembelajaran aktif tipe Card Sort dapat meningkatkan keaktifan siswa dalam menyelesaikan soal IPS khususnya pada Kompetensi Dasar Mempertahankan Kemerdekaan Indonesiamencapai 75\%".

Berdasarkan hasil tinjauan teori dan kerangka berpikir tersebut maka dapat dirumuskan hipotesis tindakan sebagai berikut:"Dengan menerapkan model pembelajaran Card Sort pada pembelajaran IPS, maka ada peningkatan aktifitas siswa dalam menyelesaikan soal IPS pada Kompetensi Dasar Mempertahankan Kemerdekaan Indonesia mencapai 75\%". Dengan demikian maka keaktifan siswa bisa berdampak pada penyelesaian soal-soal IPS dengan baiksehingga berdampak positif pada peningkatan prestasi belajar siswa".

Model pembelajaran aktif Card Sort, Hisyam Zaini, dkk (2008:50) menyatakan bahwa model ini merupakan kegiatan kolaboratif yang bisa digunakan untuk mengejar konsep, karakteristik, klasifikasi, fakta, tentang obyek atau mereview informasi. Gerakan fisik yang dominan dalam ini dapat membantu medinamiskan kelas yang jenuh dan bosan. Yang dapat membuahkan hasil belajar yangberkelanjutan hanyalah kegiatan belajar aktif. Agar belajar menjadi aktif, siswa harus banyak mengerjakan tugas. Mereka harus mengunakan otak untuk mengkaji gagasan, memecahkan masalah dan menerapkan apa yang mereka pelajari. Dengan demikian belajar yang aktif, menyenangkan dan bersemangat perlu 


\section{gulawentah: Jurnal Studi Sosial}

Volume 1 Nomor 1 Juli 2016, hal 34-40

Avaliable online at http://e-journal.ikippgrimadiun.ac.id/index.php/gulawentah

diterapkan pada mata pelajaran IPS yang selama ini dianggap pelajaran yang membosankan.

Tujuan model pembelajaran dengan menggunakan tipeCard Sortini adalah untuk mengungkapkan daya ingat terhadap materi pelajaran yang telah di pelajari siswa sehingga siswa benar-benar memahami dan mengingat pelajaran yang telah di berikan (Hartono, 2006:1)

\section{Metode Penelitian}

Penelitian ini merupakan jenis Penelitian Tindakan Kelas.Pelaksanaan tindakan oleh peneliti sendiri yang berperan sebagai guru kelas. Berdasarkan perencanaan yang telah dibuat oleh peneliti, melaksanakan tindakan pembelajaran IPS dengan menggunakan model pembelajara aktif (active learning) tipe Card SortPenelitian ini dilaksanakan di SMP Negeri 3 Kecamatan Ponorogo Kabupaten Ponorogo.

Dalam penelitian ini, instrument yang digunakan adalah pedoman observasi yang dibagi menjadi 3 bagian, yaitu; (1) observasi tindak belajar yang disesuaikan dengan rencana pembelajaran, (2) observasi tindak belajar yang berkaitan dengan kemampuan menyelesaikan soal IPS siswa kelas SMP Negeri 3 Kecamatan Ponorogo Kabupaten Ponorogo dan (3) keterangan tambahan yang berkaitan dengan tindakan mengajar maupun tindak belajar yang belum terjaring.

Teknik pengumpulan data dilakukan dengan observasi, wawancara, dokumentasi, angket dan catatan lapangan. Penelitian ini menggunakan tehnik pengumpulan data yang dibedakan menjadi dua. Metode yang digunakan yaitu metode pokok dan metode bantu. Metode pokok dengan tes dan observasi sedang metode bantu dengan dokumentasi dan cacatan lapangan.

Konsep validitas dan reliabitas instrument dalam penelitian tindakan kelas ini menggunakan jenis validasi practical validity/realibility, artinya sepanjang anggota kelompok peneitian tindakan ini memutuskan bahwa instrument dinyatakan valid dan reliable maka dapat digunakan.
Teknik analisis data dilakukan secara deskriptif kualitatif. Analisis deskriptif ini digunakan

untuk mendeskripsikanimplementasi model pembelajaran IPS yang dilakukan guru dan untuk menghitung prosentase jumlah siswa yang berhasil dalam pembelajaran tersebut. Pada penelitian ini, siswa dikatakan berhasil apabila mencapai kemampuan minimal $75 \%$ dari hasil idealnya.

Teknik analisis ini memiliki tiga komponen utama yaitu reduksi data, sajian data, dan penarikan kesimpulan serta verivikasinya (Milles, Huberman, dalam Sutopo, 2002:91). Reduksi data merupakan proses seleksi, pemfokusan, penyederhanaan, dan abstraksi data dari fiednote yang berlangsung selama pelaksanaan penelitian. Sajian data merupakan rakitan informasi, deskripsi dalam bentuk narasi yang memungkinkan simpulan peneliti dapat dilakukan, Sedangkan penarikan kesimpulan dilakukan bertahap untuk memperoleh derajat kepercayaan yang tinggi.

2wIndikator keaktifan siswa adalah 1), Di atas $75 \%$ siswa mampu mencari pasangan soal dan jawab dengan tepat.2). Di atas $75 \%$ siswa mampu menempatkan soal dan jawab pada kategori yang telah ditentukan, 3).75\% mampu menyelasaikan soal-soal IPS dengan nilai diatas KKM. Penelitian ini diharapkan dapat meningkatkan keaktifan siswa dalam menyelesaikan soal IPS pada Kompetensi Dasar Mempertahankan Kemerdekaan Indonesia dan dapat menjadikan referensi guru dalam memberikan pembelajaran di kelas. Adapun langkah-langkah yang ditempuh dalam penelitian ini adalah sebagai berikut: 1) perencanaan tindakan, 2) pelaksanaan tindakan, 3) pengamatan, 4) refleksi, 5) penyimpulan hasil berupa peningkatan aktifitas siswa dalam menyelesaikan soal IPS.

Pelaksanaan Penelitian Tindakan Kelas di lakukan dengan menggunakan 2 siklus dengan bantuan seorang kolaborator.Putaran I dilaksanakan pada hari senin tanggal 
29 September 2014. Pembelajaran yang direncanakan dilakukan melalui model pembelajaran aktif tipe Card Sort.

Tahap awal di mulai dengan pendahuluan dengan waktu 10 menit, dilanjutkan dengan kegiatan inti. 1) Guru menayangkan video Agresi Militer Belanda ke Yogyakarta di LCD di sertai tanya jawab. 2).Guru menanyakan cara yang dilakukan bangsa Indonesia melawan Belanda 3) Guru membentuk kelompok katagori, setiap kelompok 5 orang.Setelah berkumpul dalam kelompok, setiap siswa sacara individu akan di berikan tugas untuk mencari soal dan jawaban yang sesuai dengan katagori yang diberikan 4). Setelah ketemu pasangan soal dan jawaban, siswa berkumpul kembali dengan kelompok katagorinya untuk menempelkan soal dan Jawaban pada kertas karton yang telah di sediakan, setelah itu kertas karton di tempelkan papan tulis 5). Setiap kelompok katagori yang dapat mencocokan kartunya,sebelum batas waktunya diberi poin. Yang terakhir dengan kegitan penutupyang di isi dengan memberi penghargaan pada siswa yang paling baik menyelesaikan tugas, paling krearif, paling rapi membuat tugas, dan yang gigih berusaha merampungkan tugas.Juga memberikan penghargaan negatif ke siswa yang malas menyelesaikan tugas.

Refleksi (Reflecting) dilaksanakan berdasarkan observasi dan catatan. Hasil observasi meliputi lembar observasi kegiatan belajar-mengajar, lembar observasi aktivitas siswa, kuesioner motivasi siswa pada materi pembelajaran, kuosioner respon siswa terhadap pembelajaran. Catatan lapangan diantaranya soal-soal ulangan harian, lembar penilaian tugas, dan lembar observasi aktivitas bertanya siswa. Hasil observasi dan catatan lapangan dianalisis, dan dijadikan patokan pada pelaksanaan siklus berikutnya.

Pada putaran II dilaksanakan pada hari senin tanggal 13 Oktober 2014. Adapun secara umum pelaksanaan tindakan dengan menggunakan langkah-langkah yang sama dengan putran I hanya pada pendahuluan di bagian motivasi, dengan menggunakan yelyel agar pemusatan pemikiran siap belajar "AKU,KITAAYO
SIAPBELAJARSEJARAH"Pada bagian penutup di tambah dengan diadakan post test untuk mengukur seberapa jauh peserta didik mampu menguasai materi melalui model pembelajaran aktif tipe Card Sort.

\section{Hasil Penelitian dan Pembahasan}

Berdasarkan pengelaman guru kelas dan hasil observasi pendahuluan yang dilakukan peneliti, masalah kelas yang perlu segera diatasi dalam penelitian ini adalah rendahnya aktifitas belajar siswa terhadap pelajaran IPS yang berdampak pada rendahnya hasil belajar siswa dalam menyelesaikan soal-soal IPS. Setelah kegiatan merumuskan masalah di atas, dilanjutkan dengan mengidentifikasikan masalah. Kemudian menentukan juga solusi untuk memecahkan masalah tersebut.

Pada putaran I ini dominasi guru masih tampak, karena sebagian besar siswa belum mengenal strategi pembelajaran yag digunakan. Ini terlihat ketika strategi Cad sort di mulai masih banyak siswa bingung sehingga guru masih banyak memberikan penjelasan kepada siswa. Selain itu guru kurang memberikan motivasi dan bimbingan kepada siswa yang kurang berhasil. Masih banyak siswa yang kurang siap belajar, hal ini terlihat hanya 15 siswa yang mengerjakan tugas membuat soal dan jawaban yang diberikan pada pertemuan sebelumnya. Kelihatan siswa yang aktif dan kreatif adalah siswa yang memiliki kemampuan tinggi dan ternyata yang mengerjakan tugas adalah pada umumnya yang mempunyai kemampuan tinggi. Sedangkan siswa yang tidak mengerjakan tugas mengalami kesulitan dalam menjodohkan soal dan jawaban.

Untuk mengetahui tingkat keaktifan siswa dalam menyelesaikan soal IPS pada materi pelajaran mempertahankan kemerdekaan dan sejauh mana materi yang diberika dapat diterima oleh siswa maka guru memeriksa hasil pekerjaan yang ditempelkan dikarton dan hasil jawaban yang dituliskan dilembaran jawaban pada skala sikap. Adapun indikator yang dijadikan sebagai patokan untuk menilai kemampuan siswa dalam menyelesaikan soal adalah sebagai 


\section{gulawentah: Jurnal Studi Sosial}

Volume 1 Nomor 1 Juli 2016, hal 34-40

Avaliable online at http://e-journal.ikippgrimadiun.ac.id/index.php/gulawentah

berikut:Kemampuan siswa dalam menjodohkan soal dan jawaban dengan tepat b). Kemampuan siswa dalam menempatkan kartu soal atau jawaban sesuai dengan katagori dengan benar c). Kemampuan siswa menjawab soal-soal IPS dengan benar Adapun hasil dari tindakan kelas putaran I adalah kemampun siswa dalam menjawab soal dari 27 siswa yang mengikuti proses pembelajaran dan setelah diberikan kartu soal atau jawaban kemudian mencari pasangan kartu tersebut yang menjawab benar hanya 70,37 persen. Siswa yang mampu menempatkan kartu soal atau jawaban pada kategori yang telah ditentukan 66,66 persen. Kemampuan siswa menjawab soal-soal IPS dengan soal uraian pada putaran I, yang memperoleh nilai diatas 75 hanya $59,26 \%$

Tabel 1 Persentase Hasil Peningkatan Aktivitas Siswa Siklus I

\begin{tabular}{clccc}
\hline No & \multicolumn{1}{c}{ Uraian } & Hasil & Responden & $\begin{array}{c}\text { Prosentase } \\
(\%)\end{array}$ \\
\hline 1 & Menjawab benar & 19 & 27 & 70,37 \\
\hline 2 & $\begin{array}{l}\text { Menempelkan } \\
\text { Kategori benar }\end{array}$ & 18 & 27 & 66,66 \\
\hline 3 & $\begin{array}{l}\text { Menjawab soal } \\
\text { uraian benar }\end{array}$ & 16 & 27 & 59,26 \\
\hline
\end{tabular}

Pada pembelajaran putaran II ini sangat mengalami peningkatan dibandingkan dengan dari putaran sebelumnya. Siswa semakin mantap dan percaya diri karena sudah mendapat pengalaman dari putaran I. Siswa sudah menyiapkan diri dengan cara menghafal soal dan jawaban sendiri-sendiri sehingga pada saat pelaksanaan pembelajaran tipe cart sord, siswa dengan percaya diri langsung mendapatkan pasangan soal dan jawab dengan benar Siswa yang aktif mengerjakan soal dan jawaban sudah 26 siswa, sehingga pada saat menjodohkan soal dan jawaban diatas $75 \%$ sudah benar.hasilnya dari Penelitian Tindakan kelas putaran II ini yaitu kemampuan siswa menjodohkan soal dan jawaban dengan benar meningkat menjadi 92,59 persen. Sedangkan kemampuan siswa menempatkan soal dan jawaban dengan benar pada karton berdasarkan kategori 96,29 persen. Kemampuan siswa menjawab soalsoal IPS dengan soal uraian pada putaran IIjuga mengalami peningkatan karena siswa banyak yang aktif menulis pasangan soal dan jawab yang ditempel di papan tulis, bahkan siswa meminjam kertas karton yang berisi katagori kepada peneliti untuk di catat sebagai bahan untuk di pelajari menghadapi postest pada putran II. Karena itu pada putran ke- IIyang memperoleh nilai dalam menjawab soal-soal IPS diatas 75 adalah92,59\%.

Tabel 2. Persentase Hasil Peningkatan Peningkatan Aktivitas Siswa Siklus II

\begin{tabular}{llccc}
\hline No & \multicolumn{1}{c}{ Uraian } & Hasil & Responden & $\begin{array}{c}\text { Prosentase } \\
(\%)\end{array}$ \\
\hline 1 & Menjawab benar & 25 & 27 & 92,59 \\
\hline 2 & $\begin{array}{l}\text { Menempelkan } \\
\text { Kategori benar }\end{array}$ & 26 & 27 & 96,29 \\
\hline 3 & $\begin{array}{l}\text { Menjawab soal } \\
\text { uraian benar }\end{array}$ & 25 & 27 & 92,59 \\
\hline
\end{tabular}

Pada putaran siklus I dan II dari hasil pengumpulan data dari siswa dapat dijelaskan bahwa sikap siswa melalui pembelajaran aktif tipe card sort secara umum positif.Dari hasil 
angket yang disebarkan ke semua siswa menunjukkan sikap siswa terhadap pembelajaran IPS dengan strategi tipe card sort apa sangat menarik dan tidak membosankan. Pada siklus I sekitar 79,2 persen siswa menyatakan sangat setuju dan setuju terhadap pembelajaran aktif tipe card sort.Pada proes pembelajaran siklus II sikap siswa terhadap penggunaan strategi tipe card sort semakin meningkat. Siswa yang sangat setuju dan setuju sebanyak 88,88 persen, berarti meningkat sekitar 9,68\% dari siklus I

Dari angkat juga di ketahui, sikap siswa terhadap pembelaran IPS dengan menggunakan strategi tipe card sort sehingga siswa dapat menyelesaikan soal dengan baik. Hasil olahan data menunjukkan bahwa siswa yang sangat setuju dan setuju pada siklus I hanya 59,25 persen menjadi 88,88 persen pada siklus II, berarti terjadi peningkatan 29,63 persen. Sikap siswa pada pembelajaran aktif tipe card sort ini di dalam menyelesaikan soal masih ada menjawab ragu-ragu, tidak setuju dan sangat tidak setuju.

Demikian juga dengan keberanian siawa dalam mengeluarkan pendapat dari dua siklus yang dilakukan sangat setuju dan setuju meningkat. Pada siklus I siswa yang berpendapat sangat setuju dan setuju 81,48 persen, siklus II 96,29 persen, berarti terjadi peningkatan meskipun tidak terlalu besar hanya 14,81 persen.

Pada sikap siswa di dalam menggunakan strategi tipecard sort ini sehingga siswa memiliki keberania mengeluarkan pendapat akan berpengaruh terhadap peningkatan aktifitas siswa dalam menyelesaikan soal IPS. Hal ini terlihat saat proses pembelajaran berlangsung dengan model card sort siswa yang aktif menjodohkan kartu soal dan jawab dengan benar, aktif presentasi di depan kelas, dalam menjawab soal-soal IPS mendapatkan nilai di atas KKM. Dengan demikian, pembelajaran aktif tipe Card Sortdapat meningkatkan keaktifan siswa dalam pembelajaran IPS khususnya pada Kompetensi Dasar Mempertahankan Kemerdekaan Indonesia yang mempengaruhi pada penyelesaian soalsoal IPS dengan baik.

\section{Kesimpulan}

Berdasarkan hasil analisis data penelitian tindakan kelas yang dilakukan secara kolaborasi antara guru BK dengan peneliti maka disimpukan sebagai berikut: 1). Peningkatan aktifitas siswa dalam menyelesaikan soal IPS pada Kompetensi Dasar Mempertahankan Kemerdekaan Indonesia dapat dilihat dari beberapa indikator, antara lain: (a) adanya peningkatan kemampuan siswa mengerjakan tugas yang diberikan oleh guru. b) adanya peningkatan dalam mencari pasangan yang tepat antara kartu soal atau jawaban. c) adanya peningkatan dalam menjawab soal-soal IPS

Sedangkan hasil dari angket sikap siswa di peroleh data, Pada siklus I sikap siswa melalui pembelajaran aktif tipe card sort secara umum sikapnya positif. Keberanian anak untuk mengeluarkan pendapat juga semakin meningkat, Pada siklus I sekitar 81,48 persen siswa menyatakan sangat setuju dan setuju terhadap pembelajaran aktif tipe card sort. Pada proes pembelajaran siklus II sikap siswa terhadap penggunaan strategi tipe card sort semakin meningkat. Siswa yang sangat setuju dan setuju sebanyak 96,29 persen, berarti meningkat sekitar 14,81\% dari siklus I.

Dengan demikian maka dapat disimpulkan hipotesis tindakan yaitu dengan menerapkan model pembelajaran Card Sort pada pembelajaran IPS, maka ada peningkatan aktifitas siswa dalam menyelesaikan soal IPS pada Kompetensi Dasar Mempertahankan Kemerdekaan Indonesia mencapai 75\%" . Dengan demikian maka keaktifan siswa bisa meningkatkan penyelesaian soal-soal IPS dengan baiksehingga berdampak positif pada peningkatan prestasi belajar siswa".

\section{DAFTAR PUSTAKA}

Arikunto, Suharsimi. (2002). Prosedur Penelitian. Jakarta: Rineka Cipta. 
Avaliable online at http://e-journal.ikippgrimadiun.ac.id/index.php/gulawentah

Craft, Anna. (2003). Membangun Kreativitas Anak.Jakarta: Inisiasi Press.

Kurnia, Anwar, (2007). Ilmu Pengetahuan Sosial Terpadu 1. Jakarta : Ghalia Indinesia Priting. Yudistira.

Munandar, Utami. (1999). Pengembangan Kretivitas Anak Berbakat. Jakarta : Rineka Cipta.

Sardiman dkk. (2008). Pembelajaran Ilmu Pengetahuan Sosial Terpadu 1. Solo : PT Tiga Serangkai Pustaka Mandiri.

Silberman, Mel. (2006). Active Learning : 101 Cara Belajar Siswa Aktif. Diterjemahkan oleh Sarjuli dkk. Yogyakarta : Yappendid.

Slamet. (2003). Belajar dan Faktor-faktor yang Mempengaruhi. Jakarta: Rineka Cipta.

Sudjana, Nana. (2000). Dasar-Dasar Proses Belajar Mengajar. Bandung: Algesindo.

Wiriatmadja, Rochiati. (2007). Metode Penelitian Tindakan Kelas.Bandung : Remaja Rosdakarya.

Zaini, Hisyam dkk. (2008). Strategi Pembelajaran Aktif. Yogyakarta: CTSD-UIN Yogyakarta. 